\title{
Facebook and the Child - Can Parents Post their Child's Pictures on Facebook without their Consent? The Child's Right to Privacy
}

\section{Introduction}

Generally, parents love to post photographs of their children on social media such as Facebook, Twitter or Instagram, and the internet is overflowed by the posts of toddlers, young children or teenagers posted by the parents. We also like to view children's photographs, especially those who look pretty and cute. However, many of those photographs present toddlers or young children in funny situations, sometimes they are naked or running around the room only wearing their diapers. People also enjoy posting comments under photographs expressing feelings about the pictures, and congratulating parents on how beautiful and how smart their children are. At first glance, one might find nothing wrong with a beautifulphoto of a child, especially positive, cute ones which praise a child. However, after some consideration someone should ask what the child really thinks about pictures of them being posted and commented on by the strangers whom they do not know. 


\section{Source of the problem}

Even though young children are too young to care about this issue, when the children grow older they may find those pictures as embarrassing, or sometimes even offensive. Problems may especially arise when their friends start talking about those pictures and makes jokes out of them. This is especially so when parents are still keeping those pictures on Facebook and thus, post them over and over again. Those who are familiar with Facebook know that each year Facebook bring up past posts and pictures encouraging us to remind all our friends what happen during last year or year before that. ${ }^{1}$ As older children become much more aware of their privacy and could starting opposing their parents' actions. Recent studies in the United Kingdom proved that the average parent could have posted 1,498 pictures of their children on social media by the time the child turns five. This mean that the whole life of a child will be available online, in some cases, with unlimited access. ${ }^{2}$ In 2016, all newspapers around the world covered the story of an 18 year-old girl from Carinthia, Austria, who decided to sue her parents over 500 photos which they posted on Facebook and shared with 700 "friends". It was a photo book about the girl from her birth until her teenagehood. She claimed that she asked her parents multiple times to take her pictures down, but they refused to do it, so she was forced to go to court. $^{3}$ Other example is the mother of the 16 year-old Italian teenager, who was prohibited by court to post pictures of her son on Facebook without his consent, and she was ordered to remove all posted pictures from her profile. If she did not obey the court's order she would be fined 10,000 Euros. The teenager raised the issue during the divorce process of his parents, and he

$1 \quad$ N. Kobie, Could children one day sue parents for posting baby pics on Facebook? "The Guardian", Sun 8 May 2016 08.00 BST Last modified on Tue. 21 Feb 2017 17.26 GMT, https:// www.theguardian.com/sustainable-business/2016/may/08/children-sue-parents-facebook-post-baby-photos-privacy (03.02.2019).

2 J. Huggler, Austrian teenager sues parents for 'violating privacy' with childhood Facebook pictures, "The Telegraph", Berlin 14 September 2016 4:42pm, https://www.telegraph. co.uk/news/2016/09/14/austrian-teenager-sues-parents-for-violating-privacy-with-childh/ (03.02.2019).

3 A. May, 18-year-old sues parents for posting baby pictures on Facebook, "USA TODAY", Published 11:14 AM EDT Sep 16, 2016, https://eu.usatoday.com/story/news/nationnow/2016/09/16/18-year-old-sues-parents-posting-baby-pictures-facebook/90479402/ (20.01.2019). 
was considering his mother's behaviour as a violation of his private life. ${ }^{4}$ All of these examples prove, undoubtedly, that children are fully aware of their privacy and want it to be protected, even if it is against their parents' wishes.

\section{The resolution of the problem}

Article 16 of the Convention on the Rights of the Child (CRC) $)^{5}$ guarantee children such protection. According to this regulation no child should be the subject of the arbitrary or unlawful interference with his or her privacy, family, home or correspondence, nor to unlawful attacks on his or her honour and reputation. ${ }^{6}$ This right determines to protect minors from the inference or attacks from a public authority, as well as a private person. So the child's right to privacy has two dimensions: first, the protection from the unlawful interference, and secondly, the protection against an unlawful attack. It also delineates the sphere, which is private and secure, over that of the state or other interference: that is: privacy, family, home and correspondence. ${ }^{7}$ When and where the public domain possesses the right to interfere in the private sphere is easy to define, because it always has to be the rule of law which allows or obliges to interfere or to act. However, the private person's borders of non-interference or non-actions are not easy to establish. The private person's definition has to be separate on two parts: private person third person and private person - family members/ parents. When it comes

$4 \quad$ L. Smith, Woman faces $£ 9,000$ fine if she posts pictures of her son on Facebook, "Independent”, Friday 12 January 2018 13:48, https://www.independent.co.uk/news/world/ europe/facebook-fines-woman-son-photos-post-social-media-court-italy-rome-a8155361. html (29.01.2019).

5 Convention on the Rights of the Child, Adopted and opened for signature, ratification and accession by General Assembly resolution 44/25 of 20 November 1989, entry into force 2 September 1990, in accordance with article 49, https://www.ohchr.org/en/professionalinterest/pages/crc.aspx (23.01.2019).

6 Article 16 Convention on the Rights of the Child, Adopted and opened for signature, ratification and accession by General Assembly resolution 44/25 of 20 November 1989, entry into force 2 September 1990, in accordance with article 49, https://www.ohchr.org/en/professionalinterest/pages/crc.aspx, visited: 23.01.2019.

7 Sh. Derrick, A Commentary on the United Nations Convention on the Rights of the Child, London, Boston, The Hague, 1999, pp. 270-274. 
to the first part of such a definition it can be said that it is any person who has not been classified as a member of the child's family, or parent. ${ }^{8}$

In the first dimension, the state or person is obliged to withhold any actions which could lead to breach a child's right to privacy. ${ }^{9}$ Such action could include posting children's pictures on Facebook. In the second dimension, a state or person is actually taking action and is breaching the child's right to privacy. The best example of this is reading a child's dairy or published their story without their consent. ${ }^{10}$ The case of Alfie Patten proved that children need higher protection to secure their right to privacy, and their parents' interests can be, in many cases, opposite to their children's needs. Children demand protection of their privacy which is generally different from adults', especially when it comes to widely described media. Publishing a story like Alfie's, for adults in general, would be less harmful for them than for a child. A child's perspective is different from that of an adult, and their needs and expectations are also different. For Alfie's parents the interest was publicity making his story become widely recognised, or even looking for some kind of benefits from society. Alfie, as 13 old teenager, was damaged by the publicity of his case, it ruined his social and emotional life, and it had a negative impact on his future life as an adult. ${ }^{11}$

8 Sh. Derrick, A Commentary on the United Nations Convention on the Rights of the Child, London, Boston, The Hague, 1999, pp. 270-274.

9 Sh. Derrick, A Commentary on the United Nations Convention on the Rights of the Child, London, Boston, The Hague, 1999, pp. 270-279.

10 The case of the 13 year-old Alfie Patten, a "youngest dad in UK" can be recall here, when the local authorities had to ask for a court order against Alfie's parents to prevent them to contact the media in Alfie's case. Alfie, a 13 years old at the time, and Chantelle, 15 years old, hit the UK headline in 2014, when Alfie were called "the youngest dad in British history". The National newspapers were publishing pictures and a full story of Alfie, and they were informed about the story by their parents. The action of his parents almost destroyed Alfie's life and still has a problem in his adult life because of the breach of his privacy. In such a case scenario, parents should be that one who protect their child's privacy. Opposite to expected action they by allowing the press to publish Alfie's photos. He become recognised by the whole UK, and become stuck at home for several weeks, could not find a job or conduct a normal life. B. Griffiths, Having sex young wrecked my life... one minute you're playing games, the next you're a dad' says Alfie Patten, "The Sun", 27th April 2014, 5:57 am, Updated: 6th April 2016, 2:53 am. https://www.thesun.co.uk/archives/news/774574/havingsex-young-wrecked-my-life-one-minute-youre-playing-games-the-next-youre-a-dad-saysalfie-patten/ (03.02.2019).

11 M. Freeman, Law and Childhood Studies: Current Legal Issues, Volume 14, Oxford 2012, pp 474-477. 


\section{Guideline to resolution}

Article 16 of the $\mathrm{CRC}$ is, in literature, explained by article 17 of the International Covenant on Civil and Political Rights, ${ }^{12}$ which article 16 clearly resembles together with article 8 of the European Convention on Human Rights (ECHR). ${ }^{13}$ The scrutiny of court judgements, in those cases in which violation of those two were detected by the court, allowed also better understanding of the child's right to privacy. However, those judgements were in the cases when adults claim the breach of them, so the child's perspective must now be added. Taking this into consideration it can be said that the right to the privacy of the child has two major elements: the right to privacy in the strict understanding this right, and the right to a family (home). Another minor, but also important understanding, is the right to correspondence.

The European Court of Human Rights (ECHR), in several cases, define the family as a unit which is connected through close personal ties. These ties can be biological, legal, personal or emotional. The important factor in forming the answer on what a family really is is the existence of marriage and the birth of child. The legal tie creates the basics for the family definition and is predominant, whereas the fact of being born places the child immediately within the family unit. However, court sees the family as much broader and stresses also the existence of personal and emotional ties which constitute the family and family life. In some cases the personal

12 Article 17 1. No one shall be subjected to arbitrary or unlawful interference with his privacy, family, home or correspondence, nor to unlawful attacks on his honour and reputation. 2. Everyone has the right to the protection of the law against such interference or attacks [in:] International Covenant on Civil and Political Rights, Adopted and opened for signature, ratification and accession by General Assembly resolution 2200A (XXI) of 16 December 1966, entry into force 23 March 1976, in accordance with Article 49.

13 Article 8 Right to respect for private and family life 1. Everyone has the right to respect for his private and family life, his home and his correspondence. 2 . There shall be no interference by a public authority with the exercise of this right except such as is in accordance with the law and is necessary in a democratic society in the interests of national security, public safety or the economic well-being of the country, for the prevention of disorder or crime, for the protection of health or morals, or for the protection of the rights and freedoms of others in: Convention for the Protection of Human Rights and Fundamental Freedoms Rome, 4.XI.1950. 
ties overruled the biological ties. ${ }^{14}$ In the United Kingdom, in the famous case Fitzpatrick v Sterling Housing Association $\operatorname{Ltd}^{15}$ the House of Lords defined the family as a social organisation which functions through linking its members closely together. The functions of the family can be various: procreative, sexual, sociable, economic or emotional. ${ }^{16}$ A child needs the right for the protection of its family environment and family life more than adults. For a child's wellbeing, a healthy and undisturbed family life is essential to it's proper development. publishing a child's pictures in social media by the parents can disturb their family life and cause unnecessary tension. The case of the Italian teenager is an important example: when his mother used his pictures on Facebook to support her divorce case. The boy was so embarrassed by her doing so that he asked the judge for the right to move away and start a new life ${ }^{17}$.

The second major part of the definition of the right to privacy is privacy itself which the legal understanding of the privacy should establish. The English word privacy or polish word prywatny comes from Latin word privatus, which means set apart and belonging to my/you/his/herself, and is opposite to word public (polish: publiczny). Since it is difficult to defined privacy, ${ }^{18}$ the ECHR is constructing a descriptive definition of privacy, to include elements such, as concepts relating to personal identity such as name, sexuality, photo, gender or physical and moral integrity (in the strict understanding). Being a broad term it covers not only the physical integrity but also the psychological. Concentrating only on one aspect of privacy such as the photography of children, it is most important to follow the ECHR's opinion that the image constitutes a chief attribute of personality. ${ }^{19}$

14 Council of Europe/European Court of Human Rights, Guide on Article 8of the European Convention on Human Rights, 2018, pp. 46-47.

15 Fitzpatrick v Sterling Housing Association Ltd: HL 28 Oct 1999, https://publications.parliament.uk/pa/ld199899/ldjudgmt/jd991028/fitz01.htm (23.12.2018).

16 L. Glennon, Fitzpatrick v Sterling Housing Association Ltd - an endorsement of the functional family? International Journal of Law, Policy and the Family, Volume 14, Issue 3, 1 December 2000, pp. 226-255, https://doi.org/10.1093/lawfam/14.3.226. (02.02.2019)

17 S. Webb, Facebucks, Mum facing £9,000 fine for putting photos of her son, 16, on Facebook without his consent, The Sun, 11th January 2018, 4:34 pm, updated: 11th January 2018, 4:37 pm, https://www.thesun.co.uk/news/5320392/mum-facing-9000-fine-for-putting-photos-of-her-son-16-on-facebook-without-his-consent/, (22.01.2019).

18 D. L. Hudson, The Right to Privacy, Chelsea house Book, United States 2010, pp. 13.

19 Case of von Hannover v. Germany (No. 2) (Applications nos. 40660/08 and 60641/08). 
In several cases, on the grounds of breaching article 8, the ECHR court established that children as a minors should be granted special protection when it comes to photography and placing them on the internet. The Court stressed that children, as those more vulnerable need to be granted special protection, especially when posting their pictures online can be a potential threat to their physical and mental welfare. ${ }^{20}$ The case of Alfie proved this to be right without any doubts.

The ECHR and commentators of the child's right to privacy (in the strict understanding of the right) agreed that, as a principle, for the taking and publishing of a child's pictures the consent of their parents is mandatory. In a positive scenario, when parents are those who protect children's right to privacy this assumption is correct. However in the opposite scenario, when parents are those who publish child pictures without any limit, this is up to the state to protect a child's privacy. In Alfie's case it was the local authority who intervened, ${ }^{21}$ but in some cases the lawmaker is obliged to introduce the law which will protect child even against it parents' wishes. It seems wise to pass such a regulation when it comes to protecting children's privacy. The newly adopted law in France, concerning data protection is now stating that children (or teenagers) from the age of 15 can, independently from his or her parents, consent to processing his or her data in relation to information society. Child of the age under 15 must obtain consent of the holder of parental rights. This mean that a child is authorised by the holder of the parental right to consent (double consent). This means that each child/teenager of the age 15 can request the deletion of his or her personal data from the parents' Facebook account. If denied it the parents can be fined and even sent to jail. Besides, , parents should also seek consent of the minors when publishing their pictures on the Internet. ${ }^{22}$

\footnotetext{
20 M. Freeman, Law and Childhood Studies: Current Legal Issues, Volume 14, Oxford 2012, pp.477-481.

21 M. Freeman, Law and Childhood Studies: Current Legal Issues, Volume 14, Oxford 2012, pp. 476.

22 M. Saarinen, E. Auvray, F. Cruchet, Data protection in France: overview, Latham \& Watkins, https://uk.practicallaw.thomsonreuters.com/6-502-1481?transitionType=Default\& contextData $=($ sc.Default $) \&$ firstPage $=$ true $\&$ comp $=$ pluk\&bhcp $=1 \#$ co_anchor_a470789 (01.02.2019).
} 


\section{Summary}

The children's right to privacy is constituted in two major dimension which are the right to privacy, in the strict meaning, and the right to a family (home). Many parents around the world are fully aware of their children's right to privacy (in the wide sense of the word), and are not afraid to take all necessary steps to protect they children. Many cases which stand in the ECHR prove the parents' determination to protect their children. The cases K.U. v. Finland ${ }^{23}$ is a great example. However there are other negative examples when parents, sometimes even acting in good faith, are breaching the children's right to privacy. Facebook or Instagram is a great tool to share stories, but when those stories and pictures is perceived by the child as offensive, or having possible negative consequences, the child should have instruments to protects his/her privacy. Children as such need special protection when it comes to privacy, because their vulnerability in such a situation can inevitably treathen their welfare. Article 16 of the CRC, with relation to article 8, of the ECHR create the necessary legal environment for the parents and state to protect children's privacy, family and home.

\section{Bibliography}

\section{Literature:}

Council of Europe/European Court of Human Rights, Guide on Article 8 of the European Convention on Human Rights, 2018.

Derrick Sh., A Commentary on the United Nations Convention on the Rights of the Child, London, Boston, The Hague, 1999, pp. 270-274.

Freeman M., Law and Childhood Studies: Current Legal Issues, Volume 14, Oxford 2012.

Glennon L, Fitzpatrick v Sterling Housing Association Ltd - an endorsement of the functional family? International Journal of Law, Policy and the Family, Volume 14, Issue 3, 1 December 2000, pp. 226-255, https://doi.org/10.1093/ lawfam/14.3.226 (02.02.2019).

23 K.U. v. Finland, ECtHR application no. 2872/02, date 2 December 2008, https://archive.crin.org/en/library/legal-database/ku-v-finland (02.02.2019). 
Griffiths B., Having sex young wrecked my life... one minute you're playing games, the next you're a dad' says Alfie Patten, The Sun, 27th April 2014, 5:57 am, Updated: 6th April 2016, 2:53 am. https://www.thesun.co.uk/archives/news/774574/ having-sex-young-wrecked-my-life-one-minute-youre-playing-games-thenext-youre-a-dad-says-alfie-patten/ (03.02.2019).

Hudson D. L., The Right to Privacy, Chelsea house Book, United States 2010.

Huggler J., Austrian Teenager Sues Parents for 'Violating Privacy' with Childhood Facebook Pictures, “The Telegraph”, Berlin 14 September 2016 4:42pm, https:// www.telegraph.co.uk/news/2016/09/14/austrian-teenager-sues-parents-forviolating-privacy-with-childh/ (03.02.2019).

Kobie N., Could Children One Day Sue Parents for Posting Baby Pics on Facebook?, “The Guardian”, Sun 8 May 2016 08.00 BST Last modified on Tue. 21 Feb 2017 17.26 GMT, https://www.theguardian.com/sustainable-business/2016/may/08/ children-sue-parents-facebook-post-baby-photos-privacy (03.02.2019).

May A., 18-year-old Sues Parents for Posting Baby Pictures on Facebook, "USA TODAY”, Published 11:14 AM EDT Sep 16, 2016, https://eu.usatoday.com/ story/news/nation-now/2016/09/16/18-year-old-sues-parents-posting-babypictures-facebook/90479402/ (20.01.2019).

Saarinen M., Auvray E., Cruchet F., Data Protection in France: overview, Latham \& Watkins, https://uk.practicallaw.thomsonreuters.com/6-502-1481?transition Type $=$ Default $\&$ contextData $=($ sc.Default $) \&$ firstPage $=$ true $\&$ comp $=$ luk\&bhcp $=$ 1\#co_anchor_a470789 (01.02.2019).

Smith L., Woman faces $£ 9,000$ fine if she posts pictures of her son on Facebook, "Independent", Friday 12 January 2018 13:48, https://www.independent.co.uk/ news/world/europe/facebook-fines-woman-son-photos-post-social-mediacourt-italy-rome-a8155361.html (29.01.2019).

Webb S., Facebucks, Mum facing £9,000 fine for putting photos of her son, 16, on Facebook without his consent, “The Sun”, 11th January 2018, 4:34 pm, updated: 11th January 2018, 4:37 pm, https://www.thesun.co.uk/news/5320392/mumfacing-9000-fine-for-putting-photos-of-her-son-16-on-facebook-without-hisconsent/, (22.01.2019)

\section{Legal Acts}

Convention on the Rights of the Child, Adopted and opened for signature, ratification and accession by General Assembly resolution 44/25 of 20 November 1989, 
entry into force 2 September 1990, in accordance with article 49, https://www. ohchr.org/en/professionalinterest/pages/crc.aspx (23.01.2019).

Convention for the Protection of Human Rights and Fundamental Freedoms, Rome, 4.11.1950.

International Covenant on Civil and Political Rights, Adopted and opened for signature, ratification and accession by General Assembly resolution 2200A (XXI) of 16 December 1966, entry into force 23 March 1976, in accordance with Article 49.

\section{Cases}

Fitzpatrick v Sterling Housing Association Ltd: HL 28 Oct 1999, https://publications. parliament.uk/pa/ld199899/ldjudgmt/jd991028/fitz01.htm, (23.12.2018).

Case of von Hannover v. Germany (No. 2) (Applications nos. 40660/08 and 60641/08). K.U. v. Finland, ECtHR application no. 2872/02, date 2 December 2008, https:// archive.crin.org/en/library/legal-database/ku-v-finland (02.02.2019). 